This item was submitted to Loughborough's Research Repository by the author.

Items in Figshare are protected by copyright, with all rights reserved, unless otherwise indicated.

\title{
Self-perceived employability in Spain
}

PLEASE CITE THE PUBLISHED VERSION

https://doi.org/10.1108/ET-03-2017-0037

\section{PUBLISHER}

(C) Emerald

\section{VERSION}

AM (Accepted Manuscript)

\section{PUBLISHER STATEMENT}

This work is made available according to the conditions of the Creative Commons Attribution-NonCommercialNoDerivatives 4.0 International (CC BY-NC-ND 4.0) licence. Full details of this licence are available at: https://creativecommons.org/licenses/by-nc-nd/4.0/

\section{LICENCE}

CC BY-NC-ND 4.0

\section{REPOSITORY RECORD}

Vargas, Reyes, Maria Inmaculada Sanchez-Queija, Andrew T. Rothwell, and Agueda Parra. 2019. "Selfperceived Employability in Spain". figshare. https://hdl.handle.net/2134/32096. 


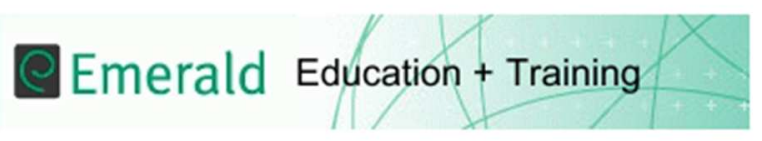

\section{Self-perceived employability in Spain}

\begin{tabular}{|r|l|}
\hline Journal: & Education + Training \\
\hline Manuscript ID & ET-03-2017-0037.R1 \\
\hline Manuscript Type: & Research Paper \\
\hline Keywords: & $\begin{array}{l}\text { Employability, Self-perceived employability, Undergraduates, Validity } \\
\text { study, Factor analysis }\end{array}$ \\
\hline \multicolumn{2}{|l}{} \\
\hline
\end{tabular}

\section{SCHOLARONE $^{\text {M }}$ \\ Manuscripts}




\section{Self-perceived employability in Spain}

\section{Abstract \\ Purpose}

The purpose of this paper is to validate in Spain the Self-perceived Employability Scale (SPE, Rothwell et al., 2008) and explore its relationship with sociodemographic variables. The SPE is an employability scale designed to examine undergraduates' expectations and self-perceptions of employability. The SPE includes an internal and external dimensions of employability and has been satisfactorily tested in a variety of contexts.

\section{Design/methodology/approach.}

The sample comprised 1502 Spanish undergraduate students from a broad range of subject areas. Confirmatory Factor Analyses (CFA) and Exploratory Factor Analyses (EFA) were conducted. Finally the Spanish-SPE (S-SPE) was studied in relation to a set of demographic variables.

\section{Findings/implications}

The results revealed similar findings to those reported by Rothwell et al. (2008), namely four factors labeled: the external labor market's demand for people in my subject field, my confidence in my skills and abilities, the status and credibility of my field of study and my engagement with my studies and academic performance. The external and internal employability dimensions were obtained by forcing a two-factor solution. Men scored higher than women in the S-SPE; science students scored higher than arts and humanities undergraduates and students with higher perceived income levels scored higher than those with lower perceived income levels.

\section{Originality/value}

The S-SPE can be used with Spanish speaking university students (Spanish being the second most widely spoken language in the world) and allows cross-cultural comparisons of undergraduates' self-perceived employability. The S-SPE may help guide the development of social policies and programs designed to enhance employability. It can be used with undergraduates as a diagnostic instrument in career counseling, and as a self-assessment instrument which will enable undergraduates to acquire a greater degree of self-knowledge in relation to their employability.

Keywords: Employability, Graduate employment, Undergraduate students.

Paper type: Research paper 
Finding and then keeping a job is a major issue in most economies. As a result of the general economic downturn, since 2008 unemployment rates have risen to $9.4 \%$ in the European Union (EU) and 22.1\% in Spain (European Commission Eurostat, 2015). Unemployment rates among the youth population are particularly alarming in Spain, where, in 2015, when the research field work described in this paper was carried out, $44.8 \%$ (a figure twice as high as the EU mean) were unable to find a job (Organisation for Economic Co-operation and Development, OECD, 2015).

In Spain, $29.4 \%$ of young people aged between 18 and 24 are university students (Ministerio de Educación, Cultura y Deporte , MECD, 2015). However, having a university degree does not guarantee employment, as is evidenced by the fact that $19.2 \%$ of those that graduated in 2010 were unemployed in 2014 (Instituto Nacional de Estadística, INE, 2015).

High unemployment rates among young university graduates reflect how hard it is for this population to find a job, and point to the need to help and support them in this undertaking (Lantarón, 2014). Even those Spanish graduates who do find employment claim that their university studies failed to provide them with the skills necessary to seek, find and hold down a job (Michavilla et al., 2016). Accordingly, the measures taken by universities to promote employability seem insufficient (Lantarón, 2014), with undergraduates failing to receive the help they require to become employable. 
In order to redress this problem and provide the support materials required to design more effective employability improvement strategies, our aim is to validate a brief questionnaire for measuring students' employability. This instrument will help fill the existing gap in empirical research into undergraduate employability in Spain, since, to date, this concept has mainly been studied either at a theoretical level or among the employed population (Alvarez et al., 2017, Qenani et al., 2014).

\section{Employability as a concept}

The concept of employability is used in different contexts and often has more than one meaning (Alvarez et al., 2017; Forrier et al., 2015). Rothwell (2015) identified four perspectives from which employability is studied. The first is the political perspective, focused on reducing unemployment and the social disadvantages it entails. This is the perspective adopted by modern-day governments, which have promoted the notion of employability linked to inclusion and skills development in the labor market (Felstead, 2013; Tymon, 2013). The principal limitation of this approach is that a focus on employability has potentially distracted from job preservation (eg. from offshoring), job creation and job sustainability (Kochan, 2012; Rothwell, 2015). The second perspective is the educational one, which focuses on graduates' access to the labor market following the rapid increase in their numbers since the late 20th century. This perspective emphasizes the role of employability in the curriculum. While this approach is well developed in other countries (Pegg, et al., 2012), it is relatively undeveloped in Spain. The third perspective is that of human resource management, which, somewhat controversially, focuses on employer-led employability strategies to enable individuals 
to sustain their careers in the light of increased job instability and insecurity (Nauta et al., 2009). Finally, the fourth perspective is the individual one, which focuses on each person's own capacity to find and keep a job of an appropriate level.

Within the individual perspective, three main approaches can be identified in the literature: competence-based employability, trait-based individual employability and self-perceived employability. The competence-based employability approach (De Vos et al., 2011) analyzes the skills and abilities which facilitate job-finding opportunities. The trait-based individual employability approach (Fugate and Kinicki, 2008) refers to proactive attitudes adopted by individuals when looking for and seeking to hold onto a job. Finally, the self-perceived employability approach focuses not just on internal personal factors related to one's perception of one's own capacities and skills for finding a job, but also on structural or external factors, such as the individual's perception of the impact of the external employment market and the importance of their qualifications or profession when trying to find a job. As a result of this twofold dimension (internal and external), the self-perceived employability approach is the most comprehensive of those developed within the individual perspective. The internal and external dimensions interact with each other, since the perception of one's own capacities and skills impacts how the external dimension is viewed, and the perception of the external market influences the perception of one's own capabilities (Batistic and Tymon, 2017).

\section{Measuring student self-perceived employability}


Within an area of research which has grown rapidly over the last decade, a number of psychometrically sound measures of student self-perceived employability have emerged. Initially these were derived from research in relation to the employed population. Rothwell and Arnold (2007) developed a 16-item questionnaire based on a quadrant-type theoretical model with the dimensions: personal attributes, occupational attributes, and the internal and external labor markets. An exploratory factor analysis with a sample of professional workers suggested that the measure was distinct from other variables, was potentially psychometrically sound $(\alpha=.83)$ and had the potential to be used either as one whole scale or as two separate ones: external employability and internal employability.

For our purposes, we have translated a scale developed in a second empirical study (Rothwell et al., 2008) conducted with 344 undergraduates. The theoretical conception of the study once again included an internal dimension, self-beliefs (D1), and an external dimension, the prevailing state of the external labor market (D2). The authors added two new dimensions related to the undergraduate sample: the impact that the university's reputation (brand image) might have on a student's employability perception (D3) and the impact of the student's particular field of study (D4). In this case, from the four dimensions and their interactions, an 8-component theoretical model emerged (see fig 1). Components are measured/evaluated by two items and are as follows: first component, my engagement with my studies and academic performance (interaction between dimensions D1 and D3); second component, my perception of the strength of the university's brand (principal component of dimension D3); third, the reputation my university has within my field of study (interaction between dimensions 
D3 and D4); fourth, the status and credibility of my field of study (principal component of dimension D4); fifth, the external labor market's demand for people in my subject field (interaction between dimensions D4 and D2); sixth, my perception of the state of the external labor market (principal component of dimension D2); seventh, my awareness of opportunities in the external labor market (interaction between dimensions D2 and D1); and finally, eighth, my confidence in my skills and abilities (principal component of dimension D1).

Figure 1 about here

An exploration of the student self-perceived employability scale's factor structure once again confirmed the existence of two factors, broadly related to external $(\alpha=.76)$ and internal $(\alpha=.66)$ employability. The first was related to the respondent's perception of the state of the external labor market, the perception of the strength of the university's brand and the status and credibility of their field of study. The second was related to self-belief (i.e. their confidence in their skills and abilities). The overall 16item scale also had good internal reliability $(\alpha=.75)$, and was further tested with a postgraduate sample (Rothwell et al., 2009). A number of subsequent studies (for example, Engelberg and Limbach-Reich, 2012; Alibaygi et al., 2013; Maiolo et al., 2013; Di Fabio, 2014; Gamboa and Paixao, 2014; Creed and Gagliardi, 2015; Huang, 2015; Goodman and Tredway, 2016; Swigon, 2016;) have also satisfactorily tested the full SPE scale in a variety of contexts, in these cases Luxembourg, Iran, Italy, Portugal, Australia, Taiwan, South Africa and Poland. The measure appeared robust as in each case internal reliabilities (Cronbach, 1951) had been .7 or above for both the overall 
scale and internal and external employability subscales (DeVellis, 2012). This suggested that, having accounted for local factors, we should be able to build on the studies described above in order to validate the employability scale with Spanish undergraduates. There are numerous adaptations of parts of the scale (for example, in a Spanish study, Caballero et al., 2017), however the scope of most components of the original scale suited our purpose well.

The aim of this present study was therefore to validate the Self-perceived Employability Scale (SPE) in Spain (S-SPE). To this end, the scale's factor structure was analyzed, along with its relationship with sociodemographic variables such as gender, family income and field of knowledge. Our definition of employability is taken as the ability to find and hold onto a job (Rothwell et al., 2008). In relation to this aim, our first hypothesis (H1) was that the factor structure of the S-SPE would be similar to that described in the previous studies listed above. On the other hand, the Spanish Employment Statistics Institute (INE, 2015) reported higher unemployment rates among women and arts and humanities graduates than among men and those with a degree in the sciences (respectively). Based on these data, our hypotheses were (H2) that men would score higher for self-perceived employability than women and (H3) that science students would score higher than arts and humanities undergraduates. In relation to income level, after Gordon (2013), we expected that (H4) those with a high purchasing power (i.e. individuals from more affluent backgrounds) would score higher than those with a low purchasing power. 


\section{Methods}

The study utilized the 16-item employability scale by Rothwell et al. (2008, 2009), to which participants respond on a Likert-type scale with anchors from strongly disagree (1) to strongly agree (5). The four items related to the D3 and D4 components ("My perception of the strength of the university's brand" and "The reputation my university has within my field of study", respectively) were excluded from our study as not being relevant in the Spanish context. In some countries (eg. the UK), the ranking of a university is considered carefully when students choose a university. However, although these university rankings have become more widely available in Spain since the implementation of the Bologna Plan in 2010 (Vidal, 2015), they are not yet an important factor in the choice of which university to attend. Spain has many public universities located all over the country, and it is precisely these public universities that are positioned highest on global league tables such as the Shanghai Ranking. The faculty selection and student admissions criteria are similar in all public universities and tuition fees vary only within a very narrow range established by the government and are similar all over the country. The criteria for obtaining research funding are also similar, and most funding is provided through competitive public calls for proposals. Only public funding obtained through competitive calls is taken into account on researchers' résumés. As a result of all this, the standing of the public universities in which $87 \%$ of Spanish students study is recognised as similar all over the country. Spanish students do not, therefore, choose their university on the basis of the strength of its brand (D3) or its reputation (D4), but rather in accordance with its proximity to their place of residence (MECD, 2015). As a result of these factors, which are unique to the Spanish context, the 
scale was simplified to 12 items. The relative irrelevance of institutional ranking had been incorporated in other international contexts while using this scale, for example Engelberg and Limbach-Reich (2012), whose Luxembourg-based study noted that employability (p. 5): '- should not be reduced to an erroneous measure of institutional advancement'.

A sociodemographic questionnaire was also administered to gather information about participants' gender and perceived family income level. Perceived family income was divided into three levels. The lowest level was indicated by positive responses to the items "At this moment in time, we have trouble making ends meet" and "We have enough to live on provided no unexpected expenses crop up". Medium-level perceived income was measured by "We have enough to live on provided no unexpected expenses crop up" and "We can go on holiday and treat ourselves every now and then". Finally, high perceived income level was reflected in the items "We're in pretty good financial shape" and "We have no financial problems". Participants were also asked about their field of study, in accordance with the category system commonly used in Spain (MECD, 2015): Arts and Humanities; Social Sciences and Legal Studies; Engineering and Architecture; Health Sciences; and Sciences.

In order to validate the factor structure of the employability construct, two Confirmatory Factor Analyses (CFA) were conducted using the statistical package AMOS, version 23.0 (Arbuckle, 2014). The CFAs aimed to validate the use of the scale as a global measure of employability (1OFM), and, as a global measure of employability made up of two factors (internal and external employability, 2O2FM). 
Due to the ordinal scaling of the items and the large sample size, the ADF (Asymptotically Distribution Free) method was chosen. The Chi-square index was used. A non-significant Chi-square is considered indicative of good fit. However, as the Chisquare value is totally dependent on sample size (Bentler and Bonnet, 1980), the CFI (Comparative Fit Index), GFI (Goodness of Fit Index) and RMSEA (Root Mean Square Error of Approximation) were also used. Models with CFI and GFI $\geq .95$ are considered to have a good fit (Hu and Bentler, 1999), although .90 is acceptable (Hooper et al., 2008). The RMSEA value should be equal to or lower than .08 in order to indicate good fit (Hu and Bentler, 1999). Since the models analyzed were not found to have a good fit, an Exploratory Factor Analysis (EFA) was carried out. Next, the EFA was repeated with a forced two-factor solution in accordance with the findings of previous studies regarding internal and external employability (for example., Rothwell et al., 2008, Huang, 2015; Goodman and Tredway, 2016;) Finally, using the SPSS ${ }^{\text {TM }}$ V.23 statistical package, mean employability scores were compared in accordance with gender, perceived family income level and the participants' field of study.

\section{Participants}

The sample comprised 1502 undergraduate students (60.1\% women, Mean age $=20.32$, SD age $=2.13$, Range age 18-29). There were more women than men in the sample group, which reflects the general situation in Spanish public universities. For example, during the 2014-15 academic year, 54.4\% of university students were female (MECD, 2015). An effort was made to recruit participants from different fields of knowledge in a representative distribution (MECD, 2015): arts and humanities (8.5\% in our sample, 
9.5\% in Spanish universities), social sciences and legal studies (32.2\%, 46.6\%), engineering and architecture $(23.5 \%, 20.2 \%)$, health sciences $(29.2 \%, 17 \%)$ and sciences $(6.7 \%, 5.7 \%)$. Data were collected during class time in the autumn of 2015. Students were assured that their answers would be treated with the utmost confidentiality. They were also informed of the purposes of the research study and told that the questionnaire was both voluntary and anonymous. None of the students in the class at the time refused to participate. The research project was approved by the Coordinating Committee for the Ethics of Biomedical Research in Andalusia (Spain).

\section{Findings}

In accordance with the theoretical framework, (Rothwell et al. 2008, 2009; inter alia), two theoretical models were tested. The first evaluated the existence of a construct called employability which is common to all 12 items (1OFM). The second model evaluated aimed to test the existence of two factors (internal and external employability) which form part of the common factor called employability (2O2FM).

The first model (1OFM), in which all 12 items were loaded on a single employability factor (see fig 2) was found not to have an acceptable fit (Table 1). In the second model (2O2FM, see fig 2), we tested whether external employability and internal employability together formed a second-order factor called employability. As shown in Table 2, none of the indexes indicated a good fit.

Figure 2 and Table 1 about here 
Given that none of the models tested was found to have a good fit, an Exploratory Factor Analysis was carried out to determine which structure best fitted the data obtained. The use of this technique was justified by the KMO index of .80 and the significance of the value obtained in Bartlett's sphericity test $\left(X^{2}(66)=4534, p<.01\right)$. The EFA was carried out by means of principal component analysis (PCA). Using the PCA, with varimax rotation, only factors with eigenvalues $>1$ were retained (Kaiser, 1958). This procedure resulted in four factors which together explained $64 \%$ of the total variance of the items. This value exceeds the criterion established by Hair et al. (2010). Table 3 shows the factor loadings obtained. We used a cutoff value of .40 to establish a solid factor loading coefficient (Swisher et al., 2004).

The results (Table 2) revealed four factors equivalent to those proposed by Rothwell et al. for undergraduates (2008) and postgraduates (2009), and confirmed by other studies (Huang, 2015; Goodman and Tredway, 2016). The internal reliability obtained for each factor is shown in Table 2. The two sub-scales which corresponded to factors 3 and 4, each of which comprised 2 items, were not found to have good internal reliability scores. The alpha indicators for factors 1 and 2 were acceptable, as was the global employability scale indicator $(\alpha=.76)$.

\section{Table 2 about here}

\section{Internal and external employability}

In order to determine whether these data could represent a two-factor structure (internal and external employability), the EFA was repeated using the same procedure but forcing a two-factor solution. The model explained $44.28 \%$ of the variance (see Table 
3). With two exceptions, the items which theoretically represent internal employability were grouped into factor 1 and those that represent external employability were grouped into factor 2. The exceptions were Item 3 “A lot more people apply for my degree than there are places available", which was not grouped into either factor; and item 9, "I can easily find out about opportunities in my chosen field", which was grouped into external employability, whereas in Rothwell et al. (2009) it formed part of the internal employability factor. The internal reliability analysis revealed Cronbach's alphas of .81 and .64 for external and internal employability, respectively.

Table 3 about here

\section{Employability and its relationship with gender, family income and field of knowledge}

Men and women's mean self-perceived employability scores were compared. The results revealed that the mean self-perceived employability score obtained by men $(M=$ 40.14) was higher than that obtained by women $(M=38.85, F(1,1492)=12.84, p<$ .001). As regards perceived family income, statistically significant differences were found $(F=9.98, p<.001)$. The post-hoc Bonferroni correction analysis revealed that these differences occurred between the lowest perceived income level (with participants in this group perceiving themselves as less employable) and the highest perceived income level.

Employability scores also differed in accordance with the field of knowledge of participants' studies $(F(4,1488)=69.75, p<.001)$. According to the Bonferroni statistic, those studying arts and humanities $(M=31.60)$ had a lower level of self- 
perceived employability than those studying degrees in other fields of knowledge. Next in order were those studying social sciences and legal studies $(M=38.41)$ and sciences $(M=38.52)$. Finally, students of engineering and architecture $(M=41.29)$ and health sciences $(M=41.31)$ were the ones who considered themselves to be most employable.

\section{Discussion}

The results obtained from the administration of the 12-item Spanish Self-perceived Employability Scale (S-SPE) to a sample of 1502 university students support the use of this instrument in a Spanish context. Although the CFAs did not support the factor structure proposed by Rothwell et al. $(2008,2009)$ and other previous studies, the two EFAs conducted did support it. The first one revealed similar results to those obtained by Rothwell et al. $(2008,2009)$, indicating that the Spanish scale comprises the same four factors: state of external labor market, self-belief, my field of study, and my engagement with my studies and academic performance. The second one pointed to the existence of two dimensions: internal and external employability. We therefore suggest that the Spanish Self-perceived Employability Scale (S-SES) is a useful and valid scale for assessing self-perceived employability and internal and external employability among Spanish university students.

As regards relationship between S-SPE and socio-demographic variables, male students scored higher on the self-perceived employability scale than their female counterparts. These findings are consistent with Spanish employment statistics. In Spain, unemployment is lower among men than among women, with $17.8 \%$ of male 
graduates under the age of 30 being unemployed, in comparison with $19.2 \%$ of female graduates (INE, 2015).

Our results also indicate that students from families with higher perceived income levels see themselves as more employable than those from families with lower perceived income levels, supporting findings from previous SPE studies (Alibaygi et al., 2013; Maiolo et al., 2013;). Their families may have their own companies or good professional contacts which would facilitate networking and provide job opportunities (Gordon, 2013). This is a potentially interesting area for further investigation in the future: historically, employability research has focused on relatively disadvantaged individuals. The impact of privilege and connections is relatively un-researched.

Finally, the results obtained with the S-SPE in the present study replicate those reported by labor market surveys and employment rates: a higher percentage of health science graduates are employed, and are therefore more employable, than their counterparts from (in descending order) engineering and architecture, arts and humanities, social sciences and sciences faculties (INE, 2015). Comparisons to the wider employability literature are difficult as previous studies have tended to be based on one field of study, such as business or psychology.

\section{Conclusion}

Our study has a number of limitations. Firstly, the S-SPE was administered in a single wave. Asking students to complete the questionnaire in a second wave would have enabled us to verify the test-retest reliability. Secondly, no other self-perceived employability instrument was used to verify the construct validity. Future research in 
this area should include complementary self-perceived employability instruments that have been validated in the Spanish context (for example, Alvarez et al., 2017). Thirdly, no additional non-demographic measures were included in the survey instrument to check discriminant validity. Previous studies have covered a wide range of variables including self-efficacy (Gamboa et al., 2014; Di Fabio 2014); ambition and university commitment ( Rothwell et al., 2008, 2009; Alibagyi et al., 2013); and well-being and career compromise (Creed and Gagliardi 2015). Testing discriminant validity is therefore a research aim for the future. Finally, this is a cross-sectional study. A longitudinal study gathering data some years after graduation would enable researchers to determine whether undergraduates who perceived themselves as more employable really were those most capable of finding a job in keeping with their qualification level upon leaving university.

Nevertheless, the study does respond to two suggestions proposed by Rothwell et al. (2009). Firstly, this study was conducted with a much larger sample (1502) of undergraduates from all areas of knowledge. This has enabled us to confirm that the instrument does indeed discriminate between students' self-perceived employability in accordance with the real demands of the employment market. Secondly, the study presented here is a replication of the scale in another country, which proves that the measure is robust also in a very different social-labor context from that found in the UK.

Our conclusion is that the Spanish Self-perceived Employability Scale (S-SES) can be used as a general measure for assessing employability as part of basic research 
activities. Being validated in different countries offers the advantage of enabling crosscultural comparisons, thus fostering advancement in the research field and improved knowledge for planning public policies aimed at enhancing the employability of university graduates. In this sense, in our opinion, the principal contribution made by this paper is the applied nature of the instrument. Due to its brevity, the scale can be used within the university environment itself as a screening instrument for detecting those students most in need of help and guidance. It can also serve to establish a baseline for the design of intervention programs in career counseling, and can be used as a self-assessment instrument to enable undergraduates to acquire a greater degree of self-knowledge in relation to their employability. As a concluding comment, we place this research paper in the context of our wider research aims. These are to help enhance the employability of young Spanish university graduates, among whom the unemployment rates in our country are alarmingly high, a circumstance that undoubtedly threatens the psychosocial well-being of those who represent both the present and future of our society. 


\section{References}

Alibaygi A.H., Barani S., Karamidehkordi E. and Pouya M. (2013), “Employability determinants of senior agricultural students in Iran", Journal of Agricultural Science and Technology, Vol. 15 No. 4, pp. 673-683.

Alvarez, P., López-Miguens, M. J. and Caballero, G. (2017), "Perceived employability in university students: developing an integrated model", Career Development International, Vol. 22 No. 3, pp. 280-299.

Arbuckle, J. L. (2014), Amos (version 23) [computer software]. Chicago, IBM: SPSS

Batistic, S. and Tymon, A. (2017), "Networking behaviour, graduate employability: a social capital perspective", Education + Training, Vol. 59 No.4, pp. 374-388.

Bentler, P. M. and Bonett, D. G. (1980), "Significance tests and goodness of fit in the analysis of covariance structures", Psychological Bulletin, Vol. 88 No. 3, pp. 588606.

Caballero, G., Álvarez, P. and López-Miguens, M. (2017), Internal determinants of university student employability, construction and validation of scales ,in: HEAd'17 (Higher Education Advances)Universitat 2017, 3rd International Conference on Higher Education Advances, 21-23 June, 2017, Valencia, Spain.

Creed P.A. and Gagliardi R.E. (2015), “Career compromise, career distress and perceptions of employability: the moderating roles of social capital and core self- 
evaluations", Journal of Career Assessment, Vol. 23 No.1, pp.20-34.

Cronbach, L. J. (1951), "Coefficient alpha and the internal structure of tests" Psychometrika, Vol.16 No.3, pp. 297 - 334.

DeVellis, R.F., (2012), Scale development: Theory and applications, $\left(3^{r d} E d n\right)$, Thousand Oaks, California, Sage.

De Vos, A., De Hauw, S. and Van der Heijden, B. I. J. M. (2011), “Competency development and career success: The mediating role of employability", Journal of Vocational Behavior, Vol. 79 No. 2, pp. 438 - 447. Di Fabio, A. (2014), "Intrapreneurial self-capital - a new construct for the $21^{\text {st }}$ century", Journal of Employment Counselling, Vol. 51 No.3, pp. 98-111.

Engelberg E. and Limbach-Reich A. (2011), “After the Bologna reform: employability of Bachelors in social and educational work in Luxembourg", Social Work Education, Vol. 31 No.4, pp. 807-818.

European Commission (2015), Eurostat, Employment and unemployment, Labour Force Survey, Total unemployed rate, available at:http://ec.europa.eu/eurostat/web/lfs/data/main-tables/(accessed 06 January 2017).

Felstead, A. (2013), "Skills at work”, Society Now, Vol. 16 Summer Issue, pp. 16-17. 
Forrier, A. and Sels, L. (2003), "The concept employability: a complex mosaic”, International Journal of Human Resources Development and Management, Vol.3 No.2, pp. 102-124.

Forrier, A., Verbruggen, M. and De Cuyper, N. (2015), "Integrating different notions of employability in a dynamic chain: The relationship between job transitions, movement capital and perceived employability", Journal of Vocational Behavior, Vol. 89, pp. 56-64.

Fugate, M. and Kinicki, A. J. (2008), “A dispositional approach to employability: Development of a measure and test of implications for employee reactions to organizational change", Journal of Occupational and Organizational Psychology, Vol. 81 No 3, pp. 503-527.

Gamboa V., Paixao O. and Palma A.I. (2014), “Adaptabilidade de Carreira e Autoeficácia na Transição para o Trabalho: O papel da Empregabilidade Percebida: Estudo com Estudantes do Ensino Superior", Revista Portuguesa de Pedagogica, Vol. 48 No. 2, pp. 133-156.

Goodman S. and Tredway G. (2016), “Antecedents of perceived graduate employability: a study of student volunteers in a community-based organization", South African Journal of Industrial Psychology, Vol. 41 No. 1, pp. 1315-1325.

Gordon, D.A.(2013), Employability and Social Class in the Graduate Labour Market, PhD. Thesis, Cardiff University, available at: https://orca.cf.ac.uk/46473/1/dg_phd.pdf 
Hair, J. F., Black, W.C., Babin, B. and Anderson, R. E. (2010), Multivariate data analysis $\left(7^{\text {th }}\right.$ Ed), Prentice Hall, New Jersey.

Hooper, D., Coughlan, J. and Mullen, M. (2008), “Structural Equation Modelling: Guidelines for Determining Model Fit”. Electronic Journal of Business Research Methods, Vol. 6 No. 1, pp. 53-60.

Hu, L. T. and Bentler, P. M. (1999), “Cutoff criteria for fit indexes in covariance structure analysis: Conventional criteria versus new alternatives", Structural Equation Modeling: a Multidisciplinary Journal, Vol. 6 No. 1, pp. 1-55.

Huang, J. (2015), “Hardiness, perceived employability, and career decision self-efficacy among taiwanese college students”, Journal of Career Development, Vol. 42 No.4, pp. 311-324.

INE, Instituto Nacional de Estadística (2015), Encuesta de Inserción Laboral de los Titulados Universitarios EILU 2014, Madrid: INE, available at:http://www.ine.es/prensa/np957.pdf /(accessed 06 January 2016).

Kaiser, H. F. (1958), “The varimax criterion for analytic rotation in factor analysis", Psychometrika, Vol. 23 No. 3, pp. 187-200.

Kochan, T. A. (2012), “A jobs compact for America’s future”, Harvard Business Review, March, available at: http://hbr.org/2012/03/a-jobs-compactforamericas- future/ar/1/ (accessed 12 October 2016).

Lantarón, B. (2014), “La empleabilidad en la Universidad Española” Journal for Educators, Teachers and Trainers, Vol. 5 No. 2, pp. 272 - 286. 
Maiolo M.E, Zuffo R.G. and Cortini M. (2013), “Students' academic performance and employability: a study on Italian undergraduates", International Journal of Learning in Higher Education, Vol. 19 No. 4, pp. 49-60.

MECD, Ministerio de Educación, Cultura y Deporte (2015), Datos y Cifras del Sistema Universitario Curso 2014/15, Madrid: MECD, Available at: http://www.mecd.gob.es/dms/mecd/educacion-mecd/areaseducacion/universidades/estadisticas-informes/datos-cifras/Datos-y-Cifras-delSUE-Curso-2014-2015.pdf (accessed 10 December 2016).

Michavilla, F., Martínez, J. M., Martín-González, M., García-Peñalvo, F. J. and CruzBenito, J. (2016), Barómetro de Empleabilidad y Empleo de los Universitarios en España, 2015 Primer informe de resultados, Observatorio de Empleabilidad y Empleo Universitarios, (online) availale at: https://gredos.usal.es/jspui/handle/10366/127374, (accessed 06 October 2016).

Nauta, A., Van Vianen, A., Van der Heijden, B., Van Dam, K. and Willemson, M. (2009), "Understanding the factors that promote employability orientation: The impact of employability culture, career satisfaction, and role breadth selfefficacy", Journal of Occupational and Organizational Psychology, Vol. 82 No. 2, pp. 233-251.

OECD Organisation for Economic Co-operation and Development (2015), Youth unemployment rate, available at:https://data.oecd.org/unemp/youthunemployment-rate.htm\#indicator-chart//(accessed 06 January 2017). 
Pegg, A., Waldock, J., Hendy-Isaac, S. and Lawton, R. (2012), Pedagogy for employability, Higher Education Academy, York, England.

Qenani, E., MacDougall N. and Sexton C., (2014), “An empirical study of selfperceived employability: improving the prospects for student employment success in an uncertain environment”, Active Learning in Higher Education, Vol. 15 No. 2 , pp. 199-213.

Rothwell, A. and Arnold, J. (2007), "Self-perceived employability: development and validation of a scale", Personnel Review, Vol. 36 No. 1, pp. 23-41.

Rothwell, A., Herbert, I. and Rothwell, F. (2008), "Self perceived employability: Construction and initial validation of a scale for university students", Journal of Vocational Behavior, Vol. 73 No. 1, pp.1-12.

Rothwell, A., Jewell, S. and Hardie, M. (2009), "Self-perceived employability: Investigating the responses of post-graduate students", Journal of Vocational Behavior, Vol. 75 No. 2, pp.152-161.

Rothwell, A. T. (2015), Employability, in Hartung, P. J., Savickas, M. L. and Walsh, W. B. (Editors-in-Chief), APA Handbook of Career Intervention: Vol. 2, Applications, Chapter 25, Vol. 2, pp. 337-350, APA: Washington DC.

Swigon M., (2016), "Self perceived employability of students of international relations of University of Warmia and Mazury in Poland", International Journal of Behavioural, Educational, Economic, Business and Industrial Engineering, Vol. 10 No. 11 , pp. 3299-3304. 
Swisher, L. L., Beckstead, J. W. and Bebeau, M. J. (2004), "Factor analysis as a tool for survey analysis using a professional role orientation inventory as an example", Physical Therapy, Vol. 84 No. 9, pp. 784-799.

Tymon, A. (2013), “The Student Perspective on Employability”, Studies in Higher Education, Vol. 38 No. 6, pp. 841-856.

Vidal, F. X. G. (2015), “Rankings, impacto cientifico y sistemas universitarios”, Monografías 2015, CRUE, Universidades Españolas, available at:

http://www.crue.org/Documentos\%20compartidos/Publicaciones/Monograf\%C3 \%ADas/RANKING XavierGrau.pdf/ (accessed 06 January 2016). 


\section{Self-perceived employability in Spain}

\section{Abstract \\ Purpose}

The purpose of this paper is to validate in Spain the Self-perceived Employability Scale (SPE, Rothwell et al., 2008) and explore its relationship with sociodemographic variables. The SPE is an employability scale designed to examine undergraduates' expectations and self-perceptions of employability. The SPE includes an internal and external dimensions of employability and has been satisfactorily tested in a variety of contexts.

\section{Design/methodology/approach.}

The sample comprised 1502 Spanish undergraduate students from a broad range of subject areas. Confirmatory Factor Analyses (CFA) and Exploratory Factor Analyses (EFA) were conducted. Finally the Spanish-SPE (S-SPE) was studied in relation to a set of demographic variables.

\section{Findings/implications}

The results revealed similar findings to those reported by Rothwell et al. (2008), namely four factors labeled: the external labor market's demand for people in my subject field, my confidence in my skills and abilities, the status and credibility of my field of study and my engagement with my studies and academic performance. The external and internal employability dimensions were obtained by forcing a two-factor solution. Men scored higher than women in the S-SPE; science students scored higher than arts and humanities undergraduates and students with higher perceived income levels scored higher than those with lower perceived income levels.

\section{Originality/value}

The S-SPE can be used with Spanish speaking university students (Spanish being the second most widely spoken language in the world) and allows cross-cultural comparisons of undergraduates' self-perceived employability. The S-SPE may help guide the development of social policies and programs designed to enhance employability. It can be used with undergraduates as a diagnostic instrument in career counseling, and as a self-assessment instrument which will enable undergraduates to acquire a greater degree of self-knowledge in relation to their employability.

Keywords: Employability, Graduate employment, Undergraduate students.

Paper type: Research paper 
Finding and then keeping a job is a major issue in most economies. As a result of the general economic downturn, since 2008 unemployment rates have risen to $9.4 \%$ in the European Union (EU) and 22.1 \% in Spain (European Commission Eurostat, 2015). Unemployment rates among the youth population are particularly alarming in Spain, where, in 2015, when the research field work described in this paper was carried out, $44.8 \%$ (a figure twice as high as the EU mean) were unable to find a job (Organisation for Economic Co-operation and Development, OECD, 2015).

In Spain, $29.4 \%$ of young people aged between 18 and 24 are university students (Ministerio de Educación, Cultura y Deporte , MECD, 2015). However, having a university degree does not guarantee employment, as is evidenced by the fact that $19.2 \%$ of those that graduated in 2010 were unemployed in 2014 (Instituto Nacional de Estadística, INE, 2015).

High unemployment rates among young university graduates reflect how hard it is for this population to find a job, and point to the need to help and support them in this undertaking (Lantarón, 2014). Even those Spanish graduates who do find employment claim that their university studies failed to provide them with the skills necessary to seek, find and hold down a job (Michavilla et al., 2016). Accordingly, the measures taken by universities to promote employability seem insufficient (Lantarón, 2014), with undergraduates failing to receive the help they require to become employable. 
In order to redress this problem and provide the support materials required to design more effective employability improvement strategies, our aim is to validate a brief questionnaire for measuring students' employability. This instrument will help fill the existing gap in empirical research into undergraduate employability in Spain, since, to date, this concept has mainly been studied either at a theoretical level or among the employed population (Alvarez et al., 2017, Qenani et al., 2014).

\section{Employability as a concept}

The concept of employability is used in different contexts and often has more than one meaning (Alvarez et al., 2017; Forrier et al., 2015). Rothwell (2015) identified four perspectives from which employability is studied. The first is the political perspective, focused on reducing unemployment and the social disadvantages it entails. This is the perspective adopted by modern-day governments, which have promoted the notion of employability linked to inclusion and skills development in the labor market (Felstead, 2013; Tymon, 2013). The principal limitation of this approach is that a focus on employability has potentially distracted from job preservation (eg. from offshoring), job creation and job sustainability (Kochan, 2012; Rothwell, 2015). The second perspective is the educational one, which focuses on graduates' access to the labor market following the rapid increase in their numbers since the late 20th century. This perspective emphasizes the role of employability in the curriculum. While this approach is well developed in other countries (Pegg, et al., 2012), it is relatively undeveloped in Spain. The third perspective is that of human resource management, which, somewhat controversially, focuses on employer-led employability strategies to enable individuals 
to sustain their careers in the light of increased job instability and insecurity (Nauta et al., 2009). Finally, the fourth perspective is the individual one, which focuses on each person's own capacity to find and keep a job of an appropriate level.

Within the individual perspective, three main approaches can be identified in the literature: competence-based employability, trait-based individual employability and self-perceived employability. The competence-based employability approach (De Vos et al., 2011) analyzes the skills and abilities which facilitate job-finding opportunities. The trait-based individual employability approach (Fugate and Kinicki, 2008) refers to proactive attitudes adopted by individuals when looking for and seeking to hold onto a job. Finally, the self-perceived employability approach focuses not just on internal personal factors related to one's perception of one's own capacities and skills for finding a job, but also on structural or external factors, such as the individual's perception of the impact of the external employment market and the importance of their qualifications or profession when trying to find a job. As a result of this twofold dimension (internal and external), the self-perceived employability approach is the most comprehensive of those developed within the individual perspective. The internal and external dimensions interact with each other, since the perception of one's own capacities and skills impacts how the external dimension is viewed, and the perception of the external market influences the perception of one's own capabilities (Batistic and Tymon, 2017).

\section{Measuring student self-perceived employability}


Within an area of research which has grown rapidly over the last decade, a number of psychometrically sound measures of student self-perceived employability have emerged. Initially these were derived from research in relation to the employed population. Rothwell and Arnold (2007) developed a 16-item questionnaire based on a quadrant-type theoretical model with the dimensions: personal attributes, occupational attributes, and the internal and external labor markets. An exploratory factor analysis with a sample of professional workers suggested that the measure was distinct from other variables, was potentially psychometrically sound $(\alpha=.83)$ and had the potential to be used either as one whole scale or as two separate ones: external employability and internal employability.

For our purposes, we have translated a scale developed in a second empirical study (Rothwell et al., 2008) conducted with 344 undergraduates. The theoretical conception of the study once again included an internal dimension, self-beliefs (D1), and an external dimension, the prevailing state of the external labor market (D2). The authors added two new dimensions related to the undergraduate sample: the impact that the university's reputation (brand image) might have on a student's employability perception (D3) and the impact of the student's particular field of study (D4). In this case, from the four dimensions and their interactions, an 8-component theoretical model emerged (see fig 1). Components are measured/evaluated by two items and are as follows: first component, my engagement with my studies and academic performance (interaction between dimensions D1 and D3); second component, my perception of the strength of the university's brand (principal component of dimension D3); third, the reputation my university has within my field of study (interaction between dimensions 
D3 and D4); fourth, the status and credibility of my field of study (principal component of dimension D4); fifth, the external labor market's demand for people in my subject field (interaction between dimensions D4 and D2); sixth, my perception of the state of the external labor market (principal component of dimension D2); seventh, my awareness of opportunities in the external labor market (interaction between dimensions D2 and D1); and finally, eighth, my confidence in my skills and abilities (principal component of dimension D1).

Figure 1 about here

An exploration of the student self-perceived employability scale's factor structure once again confirmed the existence of two factors, broadly related to external $(\alpha=.76)$ and internal $(\alpha=.66)$ employability. The first was related to the respondent's perception of the state of the external labor market, the perception of the strength of the university's brand and the status and credibility of their field of study. The second was related to self-belief (i.e. their confidence in their skills and abilities). The overall 16item scale also had good internal reliability $(\alpha=.75)$, and was further tested with a postgraduate sample (Rothwell et al., 2009). A number of subsequent studies (for example, Engelberg and Limbach-Reich, 2012; Alibaygi et al., 2013; Maiolo et al., 2013; Di Fabio, 2014; Gamboa and Paixao, 2014; Creed and Gagliardi, 2015; Huang, 2015; Goodman and Tredway, 2016; Swigon, 2016;) have also satisfactorily tested the full SPE scale in a variety of contexts, in these cases Luxembourg, Iran, Italy, Portugal, Australia, Taiwan, South Africa and Poland. The measure appeared robust as in each case internal reliabilities (Cronbach, 1951) had been .7 or above for both the overall 
scale and internal and external employability subscales (DeVellis, 2012). This suggested that, having accounted for local factors, we should be able to build on the studies described above in order to validate the employability scale with Spanish undergraduates. There are numerous adaptations of parts of the scale (for example, in a Spanish study, Caballero et al., 2017), however the scope of most components of the original scale suited our purpose well.

The aim of this present study was therefore to validate the Self-perceived Employability Scale (SPE) in Spain (S-SPE). To this end, the scale's factor structure was analyzed, along with its relationship with sociodemographic variables such as gender, family income and field of knowledge. Our definition of employability is taken as the ability to find and hold onto a job (Rothwell et al., 2008). In relation to this aim, our first hypothesis (H1) was that the factor structure of the S-SPE would be similar to that described in the previous studies listed above. On the other hand, the Spanish Employment Statistics Institute (INE, 2015) reported higher unemployment rates among women and arts and humanities graduates than among men and those with a degree in the sciences (respectively). Based on these data, our hypotheses were (H2) that men would score higher for self-perceived employability than women and (H3) that science students would score higher than arts and humanities undergraduates. In relation to income level, after Gordon (2013), we expected that (H4) those with a high purchasing power (i.e. individuals from more affluent backgrounds) would score higher than those with a low purchasing power. 


\section{Methods}

The study utilized the 16-item employability scale by Rothwell et al. (2008, 2009), to which participants respond on a Likert-type scale with anchors from strongly disagree (1) to strongly agree (5). The four items related to the D3 and D4 components ("My perception of the strength of the university's brand" and "The reputation my university has within my field of study", respectively) were excluded from our study as not being relevant in the Spanish context. In some countries (eg. the UK), the ranking of a university is considered carefully when students choose a university. However, although these university rankings have become more widely available in Spain since the implementation of the Bologna Plan in 2010 (Vidal, 2015), they are not yet an important factor in the choice of which university to attend. Spain has many public universities located all over the country, and it is precisely these public universities that are positioned highest on global league tables such as the Shanghai Ranking. The faculty selection and student admissions criteria are similar in all public universities and tuition fees vary only within a very narrow range established by the government and are similar all over the country. The criteria for obtaining research funding are also similar, and most funding is provided through competitive public calls for proposals. Only public funding obtained through competitive calls is taken into account on researchers' résumés. As a result of all this, the standing of the public universities in which $87 \%$ of Spanish students study is recognised as similar all over the country. Spanish students do not, therefore, choose their university on the basis of the strength of its brand (D3) or its reputation (D4), but rather in accordance with its proximity to their place of residence (MECD, 2015). As a result of these factors, which are unique to the Spanish context, the 
scale was simplified to 12 items. The relative irrelevance of institutional ranking had been incorporated in other international contexts while using this scale, for example Engelberg and Limbach-Reich (2012), whose Luxembourg-based study noted that employability (p. 5): ‘- should not be reduced to an erroneous measure of institutional advancement'.

A sociodemographic questionnaire was also administered to gather information about participants' gender and perceived family income level. Perceived family income was divided into three levels. The lowest level was indicated by positive responses to the items "At this moment in time, we have trouble making ends meet" and "We have enough to live on provided no unexpected expenses crop up". Medium-level perceived income was measured by "We have enough to live on provided no unexpected expenses crop up" and "We can go on holiday and treat ourselves every now and then". Finally, high perceived income level was reflected in the items "We're in pretty good financial shape" and "We have no financial problems". Participants were also asked about their field of study, in accordance with the category system commonly used in Spain (MECD, 2015): Arts and Humanities; Social Sciences and Legal Studies; Engineering and Architecture; Health Sciences; and Sciences.

In order to validate the factor structure of the employability construct, two Confirmatory Factor Analyses (CFA) were conducted using the statistical package AMOS, version 23.0 (Arbuckle, 2014). The CFAs aimed to validate the use of the scale as a global measure of employability (1OFM), and, as a global measure of employability made up of two factors (internal and external employability, 2O2FM). 
Due to the ordinal scaling of the items and the large sample size, the ADF (Asymptotically Distribution Free) method was chosen. The Chi-square index was used. A non-significant Chi-square is considered indicative of good fit. However, as the Chisquare value is totally dependent on sample size (Bentler and Bonnet, 1980), the CFI (Comparative Fit Index), GFI (Goodness of Fit Index) and RMSEA (Root Mean Square Error of Approximation) were also used. Models with CFI and GFI $\geq .95$ are considered to have a good fit (Hu and Bentler, 1999), although .90 is acceptable (Hooper et al., 2008). The RMSEA value should be equal to or lower than .08 in order to indicate good fit (Hu and Bentler, 1999). Since the models analyzed were not found to have a good fit, an Exploratory Factor Analysis (EFA) was carried out. Next, the EFA was repeated with a forced two-factor solution in accordance with the findings of previous studies regarding internal and external employability (for example., Rothwell et al., 2008, Huang, 2015; Goodman and Tredway, 2016;) Finally, using the SPSS ${ }^{\text {TM }}$ V.23 statistical package, mean employability scores were compared in accordance with gender, perceived family income level and the participants' field of study.

\section{Participants}

The sample comprised 1502 undergraduate students (60.1\% women, Mean age $=20.32$, $\mathrm{SD}$ age $=2.13$, Range age 18-29). There were more women than men in the sample group, which reflects the general situation in Spanish public universities. For example, during the 2014-15 academic year, 54.4\% of university students were female (MECD, 2015). An effort was made to recruit participants from different fields of knowledge in a representative distribution (MECD, 2015): arts and humanities (8.5\% in our sample, 
9.5\% in Spanish universities), social sciences and legal studies $(32.2 \%, 46.6 \%)$, engineering and architecture $(23.5 \%, 20.2 \%)$, health sciences $(29.2 \%, 17 \%)$ and sciences $(6.7 \%, 5.7 \%)$. Data were collected during class time in the autumn of 2015 . Students were assured that their answers would be treated with the utmost confidentiality. They were also informed of the purposes of the research study and told that the questionnaire was both voluntary and anonymous. None of the students in the class at the time refused to participate. The research project was approved by the Coordinating Committee for the Ethics of Biomedical Research in Andalusia (Spain).

\section{Findings}

In accordance with the theoretical framework, (Rothwell et al. 2008, 2009; inter alia), two theoretical models were tested. The first evaluated the existence of a construct called employability which is common to all 12 items (1OFM). The second model evaluated aimed to test the existence of two factors (internal and external employability) which form part of the common factor called employability (2O2FM).

The first model (1OFM), in which all 12 items were loaded on a single employability factor (see fig 2) was found not to have an acceptable fit (Table 1). In the second model (2O2FM, see fig 2), we tested whether external employability and internal employability together formed a second-order factor called employability. As shown in Table 2, none of the indexes indicated a good fit.

Figure 2 and Table 1 about here 
Given that none of the models tested was found to have a good fit, an Exploratory Factor Analysis was carried out to determine which structure best fitted the data obtained. The use of this technique was justified by the KMO index of .80 and the significance of the value obtained in Bartlett's sphericity test $\left(X^{2}(66)=4534, p<.01\right)$. The EFA was carried out by means of principal component analysis (PCA). Using the PCA, with varimax rotation, only factors with eigenvalues $>1$ were retained (Kaiser, 1958). This procedure resulted in four factors which together explained $64 \%$ of the total variance of the items. This value exceeds the criterion established by Hair et al. (2010). Table 3 shows the factor loadings obtained. We used a cutoff value of .40 to establish a solid factor loading coefficient (Swisher et al., 2004).

The results (Table 2) revealed four factors equivalent to those proposed by Rothwell et al. for undergraduates (2008) and postgraduates (2009), and confirmed by other studies (Huang, 2015; Goodman and Tredway, 2016). The internal reliability obtained for each factor is shown in Table 2. The two sub-scales which corresponded to factors 3 and 4, each of which comprised 2 items, were not found to have good internal reliability scores. The alpha indicators for factors 1 and 2 were acceptable, as was the global employability scale indicator $(\alpha=.76)$.

Table 2 about here

\section{Internal and external employability}

In order to determine whether these data could represent a two-factor structure (internal and external employability), the EFA was repeated using the same procedure but forcing a two-factor solution. The model explained $44.28 \%$ of the variance (see Table 
3). With two exceptions, the items which theoretically represent internal employability were grouped into factor 1 and those that represent external employability were grouped into factor 2. The exceptions were Item 3 “A lot more people apply for my degree than there are places available", which was not grouped into either factor; and item 9, "I can easily find out about opportunities in my chosen field", which was grouped into external employability, whereas in Rothwell et al. (2009) it formed part of the internal employability factor. The internal reliability analysis revealed Cronbach's alphas of .81 and .64 for external and internal employability, respectively.

Table 3 about here

\section{Employability and its relationship with gender, family income and field of knowledge}

Men and women's mean self-perceived employability scores were compared. The results revealed that the mean self-perceived employability score obtained by men $(M=$ 40.14) was higher than that obtained by women $(M=38.85, F(1,1492)=12.84, p<$ .001). As regards perceived family income, statistically significant differences were found $(F=9.98, p<.001)$. The post-hoc Bonferroni correction analysis revealed that these differences occurred between the lowest perceived income level (with participants in this group perceiving themselves as less employable) and the highest perceived income level.

Employability scores also differed in accordance with the field of knowledge of participants' studies $(F(4,1488)=69.75, p<.001)$. According to the Bonferroni statistic, those studying arts and humanities $(M=31.60)$ had a lower level of self- 
perceived employability than those studying degrees in other fields of knowledge. Next in order were those studying social sciences and legal studies $(M=38.41)$ and sciences $(M=38.52)$. Finally, students of engineering and architecture $(M=41.29)$ and health sciences $(M=41.31)$ were the ones who considered themselves to be most employable.

\section{Discussion}

The results obtained from the administration of the 12-item Spanish Self-perceived Employability Scale (S-SPE) to a sample of 1502 university students support the use of this instrument in a Spanish context. Although the CFAs did not support the factor structure proposed by Rothwell et al. $(2008,2009)$ and other previous studies, the two EFAs conducted did support it. The first one revealed similar results to those obtained by Rothwell et al. $(2008,2009)$, indicating that the Spanish scale comprises the same four factors: state of external labor market, self-belief, my field of study, and my engagement with my studies and academic performance. The second one pointed to the existence of two dimensions: internal and external employability. We therefore suggest that the Spanish Self-perceived Employability Scale (S-SES) is a useful and valid scale for assessing self-perceived employability and internal and external employability among Spanish university students.

As regards relationship between S-SPE and socio-demographic variables, male students scored higher on the self-perceived employability scale than their female counterparts. These findings are consistent with Spanish employment statistics. In Spain, unemployment is lower among men than among women, with $17.8 \%$ of male 
graduates under the age of 30 being unemployed, in comparison with $19.2 \%$ of female graduates (INE, 2015).

Our results also indicate that students from families with higher perceived income levels see themselves as more employable than those from families with lower perceived income levels, supporting findings from previous SPE studies (Alibaygi et al., 2013; Maiolo et al., 2013;). Their families may have their own companies or good professional contacts which would facilitate networking and provide job opportunities (Gordon, 2013). This is a potentially interesting area for further investigation in the future: historically, employability research has focused on relatively disadvantaged individuals. The impact of privilege and connections is relatively un-researched.

Finally, the results obtained with the S-SPE in the present study replicate those reported by labor market surveys and employment rates: a higher percentage of health science graduates are employed, and are therefore more employable, than their counterparts from (in descending order) engineering and architecture, arts and humanities, social sciences and sciences faculties (INE, 2015). Comparisons to the wider employability literature are difficult as previous studies have tended to be based on one field of study, such as business or psychology.

\section{Conclusion}

Our study has a number of limitations. Firstly, the S-SPE was administered in a single wave. Asking students to complete the questionnaire in a second wave would have enabled us to verify the test-retest reliability. Secondly, no other self-perceived employability instrument was used to verify the construct validity. Future research in 
this area should include complementary self-perceived employability instruments that have been validated in the Spanish context (for example, Alvarez et al., 2017). Thirdly, no additional non-demographic measures were included in the survey instrument to check discriminant validity. Previous studies have covered a wide range of variables including self-efficacy (Gamboa et al., 2014; Di Fabio 2014); ambition and university commitment ( Rothwell et al., 2008, 2009; Alibagyi et al., 2013); and well-being and career compromise (Creed and Gagliardi 2015). Testing discriminant validity is therefore a research aim for the future. Finally, this is a cross-sectional study. A longitudinal study gathering data some years after graduation would enable researchers to determine whether undergraduates who perceived themselves as more employable really were those most capable of finding a job in keeping with their qualification level upon leaving university.

Nevertheless, the study does respond to two suggestions proposed by Rothwell et al. (2009). Firstly, this study was conducted with a much larger sample (1502) of undergraduates from all areas of knowledge. This has enabled us to confirm that the instrument does indeed discriminate between students' self-perceived employability in accordance with the real demands of the employment market. Secondly, the study presented here is a replication of the scale in another country, which proves that the measure is robust also in a very different social-labor context from that found in the UK.

Our conclusion is that the Spanish Self-perceived Employability Scale (S-SES) can be used as a general measure for assessing employability as part of basic research 
activities. Being validated in different countries offers the advantage of enabling crosscultural comparisons, thus fostering advancement in the research field and improved knowledge for planning public policies aimed at enhancing the employability of university graduates. In this sense, in our opinion, the principal contribution made by this paper is the applied nature of the instrument. Due to its brevity, the scale can be used within the university environment itself as a screening instrument for detecting those students most in need of help and guidance. It can also serve to establish a baseline for the design of intervention programs in career counseling, and can be used as a self-assessment instrument to enable undergraduates to acquire a greater degree of self-knowledge in relation to their employability. As a concluding comment, we place this research paper in the context of our wider research aims. These are to help enhance the employability of young Spanish university graduates, among whom the unemployment rates in our country are alarmingly high, a circumstance that undoubtedly threatens the psychosocial well-being of those who represent both the present and future of our society. 


\section{References}

Alibaygi A.H., Barani S., Karamidehkordi E. and Pouya M. (2013), “Employability determinants of senior agricultural students in Iran", Journal of Agricultural Science and Technology, Vol. 15 No. 4, pp. 673-683.

Alvarez, P., López-Miguens, M. J. and Caballero, G. (2017), "Perceived employability in university students: developing an integrated model", Career Development International, Vol. 22 No. 3, pp. 280-299.

Arbuckle, J. L. (2014), Amos (version 23) [computer software]. Chicago, IBM: SPSS

Batistic, S. and Tymon, A. (2017), "Networking behaviour, graduate employability: a social capital perspective", Education + Training, Vol. 59 No.4, pp. 374-388.

Bentler, P. M. and Bonett, D. G. (1980), "Significance tests and goodness of fit in the analysis of covariance structures”, Psychological Bulletin, Vol. 88 No. 3, pp. 588606.

Caballero, G., Álvarez, P. and López-Miguens, M. (2017), Internal determinants of university student employability, construction and validation of scales ,in: HEAd'17 (Higher Education Advances)Universitat 2017, 3rd International Conference on Higher Education Advances, 21-23 June, 2017, Valencia, Spain.

Creed P.A. and Gagliardi R.E. (2015), “Career compromise, career distress and perceptions of employability: the moderating roles of social capital and core self- 
evaluations", Journal of Career Assessment, Vol. 23 No.1, pp.20-34.

Cronbach, L. J. (1951), "Coefficient alpha and the internal structure of tests" Psychometrika, Vol.16 No.3, pp. 297 - 334.

DeVellis, R.F., (2012), Scale development: Theory and applications, $\left(3^{r d} E d n\right)$, Thousand Oaks, California, Sage.

De Vos, A., De Hauw, S. and Van der Heijden, B. I. J. M. (2011), “Competency development and career success: The mediating role of employability", Journal of Vocational Behavior, Vol. 79 No. 2, pp. 438 - 447. Di Fabio, A. (2014), "Intrapreneurial self-capital - a new construct for the $21^{\text {st }}$ century", Journal of Employment Counselling, Vol. 51 No.3, pp. 98-111.

Engelberg E. and Limbach-Reich A. (2011), “After the Bologna reform: employability of Bachelors in social and educational work in Luxembourg", Social Work Education, Vol. 31 No.4, pp. 807-818.

European Commission (2015), Eurostat, Employment and unemployment, Labour Force Survey, Total unemployed rate, available at:http://ec.europa.eu/eurostat/web/lfs/data/main-tables/(accessed 06 January 2017).

Felstead, A. (2013), “Skills at work”, Society Now, Vol. 16 Summer Issue, pp. 16-17. 
Forrier, A. and Sels, L. (2003), "The concept employability: a complex mosaic”, International Journal of Human Resources Development and Management, Vol.3 No.2, pp. 102-124.

Forrier, A., Verbruggen, M. and De Cuyper, N. (2015), "Integrating different notions of employability in a dynamic chain: The relationship between job transitions, movement capital and perceived employability", Journal of Vocational Behavior, Vol. 89, pp. 56-64.

Fugate, M. and Kinicki, A. J. (2008), “A dispositional approach to employability: Development of a measure and test of implications for employee reactions to organizational change", Journal of Occupational and Organizational Psychology, Vol. 81 No 3, pp. 503-527.

Gamboa V., Paixao O. and Palma A.I. (2014), “Adaptabilidade de Carreira e Autoeficácia na Transição para o Trabalho: O papel da Empregabilidade Percebida: Estudo com Estudantes do Ensino Superior", Revista Portuguesa de Pedagogica, Vol. 48 No. 2, pp. 133-156.

Goodman S. and Tredway G. (2016), “Antecedents of perceived graduate employability: a study of student volunteers in a community-based organization”, South African Journal of Industrial Psychology, Vol. 41 No. 1, pp. 1315-1325.

Gordon, D.A.(2013), Employability and Social Class in the Graduate Labour Market, PhD. Thesis, Cardiff University, available at: https://orca.cf.ac.uk/46473/1/dg_phd.pdf 
Hair, J. F., Black, W.C., Babin, B. and Anderson, R. E. (2010), Multivariate data analysis $\left(7^{\text {th }}\right.$ Ed), Prentice Hall, New Jersey.

Hooper, D., Coughlan, J. and Mullen, M. (2008), "Structural Equation Modelling: Guidelines for Determining Model Fit”. Electronic Journal of Business Research Methods, Vol. 6 No. 1, pp. 53-60.

Hu, L. T. and Bentler, P. M. (1999), “Cutoff criteria for fit indexes in covariance structure analysis: Conventional criteria versus new alternatives", Structural Equation Modeling: a Multidisciplinary Journal, Vol. 6 No. 1, pp. 1-55.

Huang, J. (2015), “Hardiness, perceived employability, and career decision self-efficacy among taiwanese college students", Journal of Career Development, Vol. 42 No.4, pp. 311-324.

INE, Instituto Nacional de Estadística (2015), Encuesta de Inserción Laboral de los Titulados Universitarios EILU 2014, Madrid: INE, available at:http://www.ine.es/prensa/np957.pdf/(accessed 06 January 2016).

Kaiser, H. F. (1958), “The varimax criterion for analytic rotation in factor analysis", Psychometrika, Vol. 23 No. 3, pp. 187-200.

Kochan, T. A. (2012), “A jobs compact for America's future”, Harvard Business Review, March, available at: http://hbr.org/2012/03/a-jobs-compactforamericas- future/ar/1/ (accessed 12 October 2016).

Lantarón, B. (2014), “La empleabilidad en la Universidad Española” Journal for Educators, Teachers and Trainers, Vol. 5 No. 2, pp. 272 - 286. 
Maiolo M.E, Zuffo R.G. and Cortini M. (2013), “Students' academic performance and employability: a study on Italian undergraduates", International Journal of Learning in Higher Education, Vol. 19 No. 4, pp. 49-60.

MECD, Ministerio de Educación, Cultura y Deporte (2015), Datos y Cifras del Sistema Universitario Curso 2014/15, Madrid: MECD, Available at: http://www.mecd.gob.es/dms/mecd/educacion-mecd/areaseducacion/universidades/estadisticas-informes/datos-cifras/Datos-y-Cifras-delSUE-Curso-2014-2015.pdf (accessed 10 December 2016).

Michavilla, F., Martínez, J. M., Martín-González, M., García-Peñalvo, F. J. and CruzBenito, J. (2016), Barómetro de Empleabilidad y Empleo de los Universitarios en España, 2015 Primer informe de resultados, Observatorio de Empleabilidad y Empleo Universitarios, (online) availale at: https://gredos.usal.es/jspui/handle/10366/127374, (accessed 06 October 2016).

Nauta, A., Van Vianen, A., Van der Heijden, B., Van Dam, K. and Willemson, M. (2009), "Understanding the factors that promote employability orientation: The impact of employability culture, career satisfaction, and role breadth selfefficacy", Journal of Occupational and Organizational Psychology, Vol. 82 No. 2, pp. 233-251.

OECD Organisation for Economic Co-operation and Development (2015), Youth unemployment rate, available at:https://data.oecd.org/unemp/youthunemployment-rate.htm\#indicator-chart//(accessed 06 January 2017). 
Pegg, A., Waldock, J., Hendy-Isaac, S. and Lawton, R. (2012), Pedagogy for employability, Higher Education Academy, York, England.

Qenani, E., MacDougall N. and Sexton C., (2014), “An empirical study of selfperceived employability: improving the prospects for student employment success in an uncertain environment", Active Learning in Higher Education, Vol. 15 No. 2, pp. 199-213.

Rothwell, A. and Arnold, J. (2007), “Self-perceived employability: development and validation of a scale", Personnel Review, Vol. 36 No. 1, pp. 23-41.

Rothwell, A., Herbert, I. and Rothwell, F. (2008), "Self perceived employability: Construction and initial validation of a scale for university students", Journal of Vocational Behavior, Vol. 73 No. 1, pp.1-12.

Rothwell, A., Jewell, S. and Hardie, M. (2009), “Self-perceived employability: Investigating the responses of post-graduate students", Journal of Vocational Behavior, Vol. 75 No. 2, pp.152-161.

Rothwell, A. T. (2015), Employability, in Hartung, P. J., Savickas, M. L. and Walsh, W. B. (Editors-in-Chief), APA Handbook of Career Intervention: Vol. 2, Applications, Chapter 25, Vol. 2, pp. 337-350, APA: Washington DC.

Swigon M., (2016), "Self perceived employability of students of international relations of University of Warmia and Mazury in Poland”, International Journal of Behavioural, Educational, Economic, Business and Industrial Engineering, Vol. 10 No. 11, pp. 3299-3304. 
Swisher, L. L., Beckstead, J. W. and Bebeau, M. J. (2004), "Factor analysis as a tool for survey analysis using a professional role orientation inventory as an example", Physical Therapy, Vol. 84 No. 9, pp. 784-799.

Tymon, A. (2013), “The Student Perspective on Employability”, Studies in Higher Education, Vol. 38 No. 6, pp. 841-856.

Vidal, F. X. G. (2015), “Rankings, impacto cientifico y sistemas universitarios”, Monografías 2015, CRUE, Universidades Españolas, available at:

http://www.crue.org/Documentos\%20compartidos/Publicaciones/Monograf\%C3 \%ADas/RANKING XavierGrau.pdf/ (accessed 06 January 2016). 
Figure 1. Student self-perceived employability

\begin{tabular}{|c|c|c|}
\hline \multicolumn{3}{|c|}{ My University (D3) } \\
\hline $\begin{array}{l}\text { 1.My } \\
\text { engagement } \\
\text { with my studies } \\
\text { and academic } \\
\text { performance }\end{array}$ & $\begin{array}{l}\text { 2.My } \\
\text { perception of } \\
\text { the strength of } \\
\text { the } \\
\text { university's } \\
\text { brand. }\end{array}$ & $\begin{array}{l}\text { 3. The } \\
\text { reputation my } \\
\text { university has } \\
\text { within my } \\
\text { field of study }\end{array}$ \\
\hline $\begin{array}{l}\text { 8.My confidence } \\
\text { in my skills and } \\
\text { abilities }\end{array}$ & My ambition & $\begin{array}{l}\text { 4. The status } \\
\text { and credibility } \\
\text { of my field of } \\
\text { study }\end{array}$ \\
\hline $\begin{array}{l}\text { 7.My awareness } \\
\text { of opportunities } \\
\text { in } \\
\text { the external } \\
\text { labour market }\end{array}$ & $\begin{array}{l}\text { 6.My } \\
\text { perception of } \\
\text { the } \\
\text { state of the } \\
\text { external } \\
\text { labour market }\end{array}$ & $\begin{array}{l}\text { 5. The external } \\
\text { labour } \\
\text { market's } \\
\text { demand for } \\
\text { people in my } \\
\text { subject } \\
\text { field }\end{array}$ \\
\hline
\end{tabular}

Source: Rothwell et al., (2008) 
Figure 2. Theoretical Model Analysed

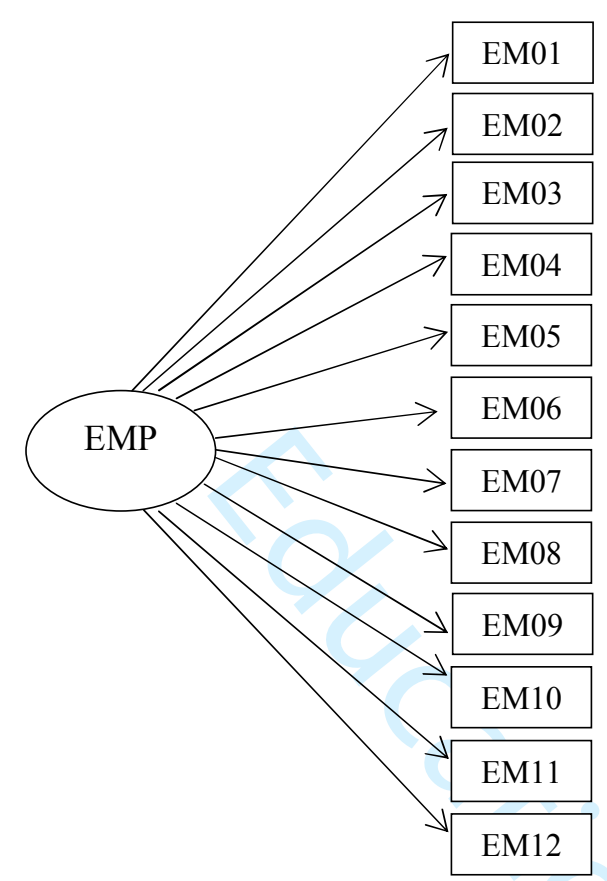

1OF: First Order Factor Model

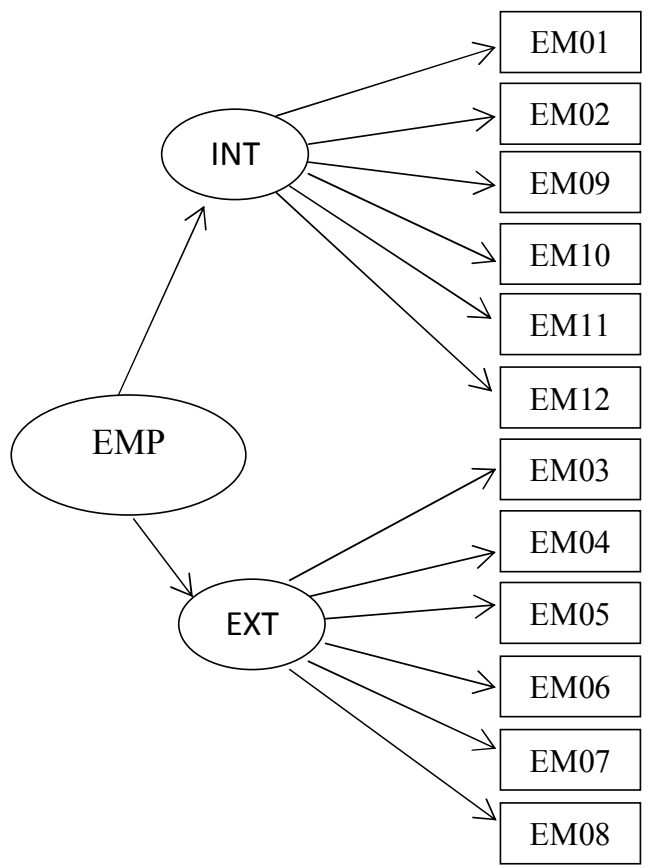

2O2FM: Second Order and Two First Order Factor Model 
Table 1. Goodness-of-fit indexes of the employability models

\begin{tabular}{ccccc}
\hline & $\boldsymbol{X}^{\mathbf{2}}(\mathbf{g l}), \boldsymbol{p}$ & $\boldsymbol{C F I}$ & $\boldsymbol{G F I}$ & $\boldsymbol{R M S E A}$ \\
\hline 1OFM & $832.48(108), p<.001$ & .49 & .87 & .067 \\
202FM & $1213,28(55), p<.001$ & .41 & .79 & .118 \\
\hline
\end{tabular}

Note: $N=1502, \mathbf{1 O F M}=$ first-order model, 2O2FM $=$ second-order model $(2 \mathrm{first}$ order factors), $X^{2}=$ Chi square statistic, $C F I=$ Comparative Fit Index, $G F I=$ Goodness of Fit Index, RMSEA = Root Mean Square Error of Approximation 
Table 2.Varimax rotation of the four-factor solution for the employability scale, percentage of variance explained and internal reliability.

\begin{tabular}{|c|c|c|c|c|}
\hline $\begin{array}{l}\text { Items (see } \\
\text { Appendix A) }\end{array}$ & Factor 1 & Factor 2 & Factor 3 & Factor 4 \\
\hline EM8 & .84 & & & \\
\hline EM9 & .84 & & & \\
\hline EM5 & .77 & & & \\
\hline EM7 & .54 & & & \\
\hline EM6 & .52 & & .41 & \\
\hline EM11 & & .81 & & \\
\hline EM12 & & .81 & & \\
\hline EM10 & & & & \\
\hline EM3 & & & .83 & \\
\hline EM4 & .43 & & .59 & \\
\hline EM1 & & & & .83 \\
\hline EM2 & & & & .78 \\
\hline $\begin{array}{l}\text { Percentage of } \\
\text { variance } \\
\text { explained }\end{array}$ & $29.74 \%$ & $14.54 \%$ & $10.79 \%$ & $8.47 \%$ \\
\hline Cronbach'sAlpha & .79 & .72 & .45 & .50 \\
\hline
\end{tabular}

Note: F1: The external labor market's demand for people in my subject field. F2: My confidence in my skills and abilities. F3: The status and credibility of my field of study. F4: My engagement with my studies and academic performance. 
Table 3.Varimax rotation of the two-factor solution for the employability scale, percentage of variance explained and internal reliability.

\begin{tabular}{lcc}
\hline Items & F1 & F2 \\
\hline EM5 & .82 & \\
EM8 & .77 & \\
EM9 & .77 & \\
EM6 & .63 & \\
EM7 & .62 & \\
EM4 & .60 & .73 \\
EM10 & & .67 \\
EM12 & & .65 \\
EM11 & & .54 \\
EM1 & & .64 \\
EM2 & & .53 \\
EM3 & & \\
\hline Percentaje of & & \\
variance explained & & \\
\hline Cronbach'sAlpha & & \\
\hline
\end{tabular}

Note: F1: External Employability. F2: Internal Employability 
Appendix A. The self-perceived employability scale

\begin{tabular}{|c|c|c|c|}
\hline & SPANISH & ORIGINAL ENGLISH VERSI & \\
\hline EM1 & $\begin{array}{l}\text { Consigo buenas notas en mis } \\
\text { estudios }\end{array}$ & $\begin{array}{l}\text { I achieve high grades in relation to } \\
\text { my studies }\end{array}$ & $1 \mathbf{a}$ \\
\hline EM2 & $\begin{array}{l}\text { Mis estudios son una prioridad } \\
\text { para mí }\end{array}$ & $\begin{array}{l}\text { I regard my academic work as top } \\
\text { priority }\end{array}$ & $\mathbf{1 b}$ \\
\hline EM3 & $\begin{array}{l}\text { Hay muchas más solicitudes para } \\
\text { entrar en mis estudios que plazas } \\
\text { disponibles }\end{array}$ & $\begin{array}{l}\text { A lot more people apply for my } \\
\text { degree than there are places } \\
\text { available. }\end{array}$ & $4 \mathbf{a}$ \\
\hline EM4 & $\begin{array}{l}\text { Mis estudios tienen un estatus } \\
\text { social muy elevado }\end{array}$ & $\begin{array}{l}\text { My chosen subject(s) rank(s) highly } \\
\text { in terms of social status }\end{array}$ & $4 b$ \\
\hline EM5 & $\begin{array}{l}\text { La gente que cursa mis estudios } \\
\text { está muy demandada en el } \\
\text { mercado laboral }\end{array}$ & $\begin{array}{l}\text { People in the career I am aiming for } \\
\text { are in high demand in the external } \\
\text { labour market }\end{array}$ & $5 \mathbf{a}$ \\
\hline EM6 & $\begin{array}{l}\text { Mi formación es la mejor para } \\
\text { ejercer una profesión percibida } \\
\text { como muy deseable }\end{array}$ & $\begin{array}{l}\text { My degree is seen as leading to a } \\
\text { specific career that is generally } \\
\text { perceived as highly desirable }\end{array}$ & $5 \mathbf{b}$ \\
\hline EM7 & $\begin{array}{l}\text { Hay una fuerte demanda de } \\
\text { graduados en este momento }\end{array}$ & $\begin{array}{l}\text { There is generally a strong demand } \\
\text { for graduates at the present time }\end{array}$ & $\mathbf{6 a}$ \\
\hline EM8 & $\begin{array}{l}\text { Hay muchas ofertas de empleo en } \\
\text { el área geográfica en la que estoy } \\
\text { buscando }\end{array}$ & $\begin{array}{l}\text { There are plenty of job vacancies in } \\
\text { the geographical area where I am } \\
\text { looking }\end{array}$ & $6 \mathbf{b}$ \\
\hline EM9 & $\begin{array}{l}\text { Puedo encontrar fácilmente } \\
\text { oportunidades en mi área laboral }\end{array}$ & $\begin{array}{l}\text { I can easily find out about } \\
\text { opportunities in my chosen field }\end{array}$ & $7 \mathbf{a}$ \\
\hline EM10 & $\begin{array}{l}\text { Tengo las habilidades y } \\
\text { competencias que los } \\
\text { empleadores buscan }\end{array}$ & $\begin{array}{l}\text { The skills and abilities that I } \\
\text { possess are what employers are } \\
\text { looking for. }\end{array}$ & $7 \mathbf{b}$ \\
\hline EM11 & $\begin{array}{l}\text { Normalmente confío en mi éxito } \\
\text { cuando acudo a procesos de } \\
\text { selección de personal o a } \\
\text { entrevistas de trabajo }\end{array}$ & $\begin{array}{l}\text { I am generally confident of success } \\
\text { in job Interviews and selection } \\
\text { events }\end{array}$ & $8 \mathbf{a}$ \\
\hline EM12 & $\begin{array}{l}\text { Tengo habilidades y experiencia } \\
\text { suficientemente buenas como } \\
\text { para encontrar trabajo }\end{array}$ & $\begin{array}{l}\text { I feel I could get any job so long as } \\
\text { my skills and experience are } \\
\text { reasonably relevant }\end{array}$ & $8 \mathbf{b}$ \\
\hline
\end{tabular}

